\title{
Silage production and bromatological constitution effects of corn hybrids in different environments
}

\section{Efeitos na produção e constituição bromatológica de silagem de híbridos de milho em diferentes ambientes}

\author{
Ivan Ricardo Carvalho ${ }^{*}$, Velci Queiróz de Souza², Diego Nicolau Follmann², Maicon Nardino, \\ Alan Junior de Pelegrin², Mauricio Ferrari ${ }^{1}$, Valmor Antonio Konflanz ${ }^{3}$, Rafael Lazzari² e Juliano \\ Uczay 4
}

\author{
${ }^{1}$ Centro de Genômica e Fitomelhoramento, UFPel, Campus Universitário, s/n, 96010-165 Capão do Leão, RS, Brasil; \\ 2 Laboratório de Melhoramento Genético e Produção de Plantas, UFSM/FW, Linha 7 de Setembro, s/n, BR 386 Km 4098400-000, Frederico Westphalen, RS, Brasil; \\ ${ }_{3}^{3}$ KSP Seeds, Rua Aimoré, 991, Centro, 85504-050, Pato Branco, PR, Brasil; \\ 4 Universidade do Estado de Santa Catarina, Av. Luís de Camões, 2090, Conta Dinheiro, 88520-000, Lages, SC, Brasil. \\ ( ${ }^{\star} E-m a i l:$ carvalho.irc@gmail.com) \\ http://dx.doi.org/10.19084/RCA15130
}

Received/recebido: 2015.09.30

Accepted/aceite: 2015.10 .28

\begin{abstract}
A B S T R A C T
The aim of this study was to assess silage corn hybrids morphological, productive and bromatological parameters in irrigated and non-irrigated environmental conditions. The research was held in the 2010/2011 season, Campos Borges RS. The experimental design was randomized blocks in factorial design, with two environments x eight corn hybrids, arranged in three replications. Analysis of variance showed environment $x$ corn hybrids interaction significance for plant height, fresh and dry matter per hectare, dry matter percentage, mineral matter, crude protein, neutral detergent fiber, lignin, total and non-fibrous carbohydrates. In the irrigated environment, hybrids showed higher plant height, chlorophyll content, leaf area, fresh and dry matter per hectare, silage dry matter percentage, $\mathrm{pH}$, mineral material, neutral detergent fiber, cellulose and lignin. Non-fibrous and total carbohydrate levels were higher for the non-irrigated environment. Crude protein content was higher in the non-irrigated environment. In the irrigated environment HS1356 hybrid showed higher plant height, fresh and dry matter per hectare, mineral material and neutral detergent fiber. HT4 hybrid led to higher silage crude protein content in the irrigated environment.
\end{abstract}

Keywords: irrigation, nutritional parameters, silage, Zea mays L.

\section{R E S U M O}

O objetivo do trabalho foi avaliar os parâmetros morfológicos, produtivos e bromatológicos de híbridos de milho para silagem em condições de ambiente irrigado e sequeiro. Realizado na safra agrícola 2010/2011 em Campos Borges - RS. O delineamento experimental utilizado foi de blocos ao acaso em esquema fatorial, sendo dois ambientes x oito híbridos, dispostos em três repetições. A análise de variância revelou significância para interação ambiente $\mathrm{x}$ híbridos de milho paraaltura de planta, massa fresca e seca por hectare, percentagem de matéria seca, material mineral, proteína bruta, fibra em detergente neutro, lignina, carboidratos totais e não fibrosos. No ambiente irrigado os híbridos apresentam maior altura de planta, teor de clorofila, área foliar, massa fresca e seca por hectare, percentagem de matéria seca na silagem, $\mathrm{pH}$, material mineral, fibra em detergente neutro, celulose e lignina. Os teores de carboidratos não fibrosos e carboidratos totais revelaram-sesuperiores para o ambientesequeiro. O teor de proteína bruta apresentou-se mais elevado em sequeiro. O híbrido HS1356 mostrou-se superior em ambiente irrigado para os caracteres altura de planta, massa fresca e seca por hectare, material mineral e fibra em detergente neutro. Em ambiente irrigado o híbrido HT4 originou um maior teor de proteína bruta na silagem.

Palavras - chave: ensilagem, irrigação, parâmetros nutricionais, Zea mays L. 


\section{INTRODUCTION}

Corn silage use provides voluminous food of high bromatological quality offer, increasing dry matter intake and enabling better food use in the digestive tract of animals. High quality silage production requires between $30 \%$ and $35 \%$ dry matter contents, soluble carbohydrates, $\mathrm{pH}$ decrease in silage fermentation, brief aerobic period and oxygen consumption in the silage mass, intense anaerobiosis with lactic bacteria action and a fermentation process of adequate occurrence (Ferrari Junior et al., 2005). Corn hybrid choice is important to the success of the process. In contrast, silage chemical composition is dependent on factors as genetic constitution, climate and soil conditions, harvest stage, fermentation process and storage.

Rain seasonality and frequent water restrictions cause negative effects to culture when they occur between flowering and physiological maturity, causing low fertility of pollen grains, affecting synchronism between male and female inflorescences, reducing cob grains, decreasing leaf expansion, influencing protein synthesis metabolites and decreasing plant height and vigor (Carvalho et al., 2013).

These characters directly influence crop production and chemical quality. Thus, the goal of this study was to evaluate morphological, productive and bromatological parameters of silage corn hybrids in irrigated and non-irrigated environmental conditions.

\section{MATERIAL AND METHODS}

The experiment was carried out in the 2010/2011 agricultural harvest, municipality of Campos Borges - RS, in a dark-red Latosol. Climate is Cfa subtropical according to Köppen classification. Geographical coordinates are: Latitude: $28^{\circ} 55^{\prime} 36.02^{\prime \prime} \mathrm{S}$, Longitude: $53^{\circ} 01^{\prime} 40.34^{\prime \prime} \mathrm{O}$, with 513 meters altitude. The experimental design was of randomized blocks in a factorial scheme $(2 \times 8)$ of two environments $\mathrm{x}$ eight corn hybrids, in three repetitions, totaling 48 experimental units. Assessed environments were non-irrigated and irrigated. Used hybrids were the following: HT3248, HS1356, HS13802, HS1358, HT7, HSM97, HS1380-1 and HT4 with a density of 75 plants per hectare. Irrigation depth management (Figure 1) was solely based on adding $15 \mathrm{~mm}$ water every ten days during the crop cycle through sprinkler irrigation system.

Harvest was homogeneous among environments and hybrids, and plant grains were milky to chalky. Plants were grinded in 10 to $20 \mathrm{~mm}$ particles, being ensiled in PVC mini-silos with dimensions of $50 \mathrm{~cm}$ by $10 \mathrm{~cm}$ diameter. On the mini-silo base, sieved dry sand was annexed in order to store solutes resulting from the silage process fermentation. Silage was compacted with $600 \mathrm{~kg}$ fresh matter per cubic meter density. Subsequently, mini-silos were tightly sealed and stored for 820 days.

Analyzed parameters were: plant height $(\mathrm{PH})$ : measured from ground level to the last expanded leaf (m); chlorophyll content (CC): obtained through readings with SPAD-502 chlorophyll

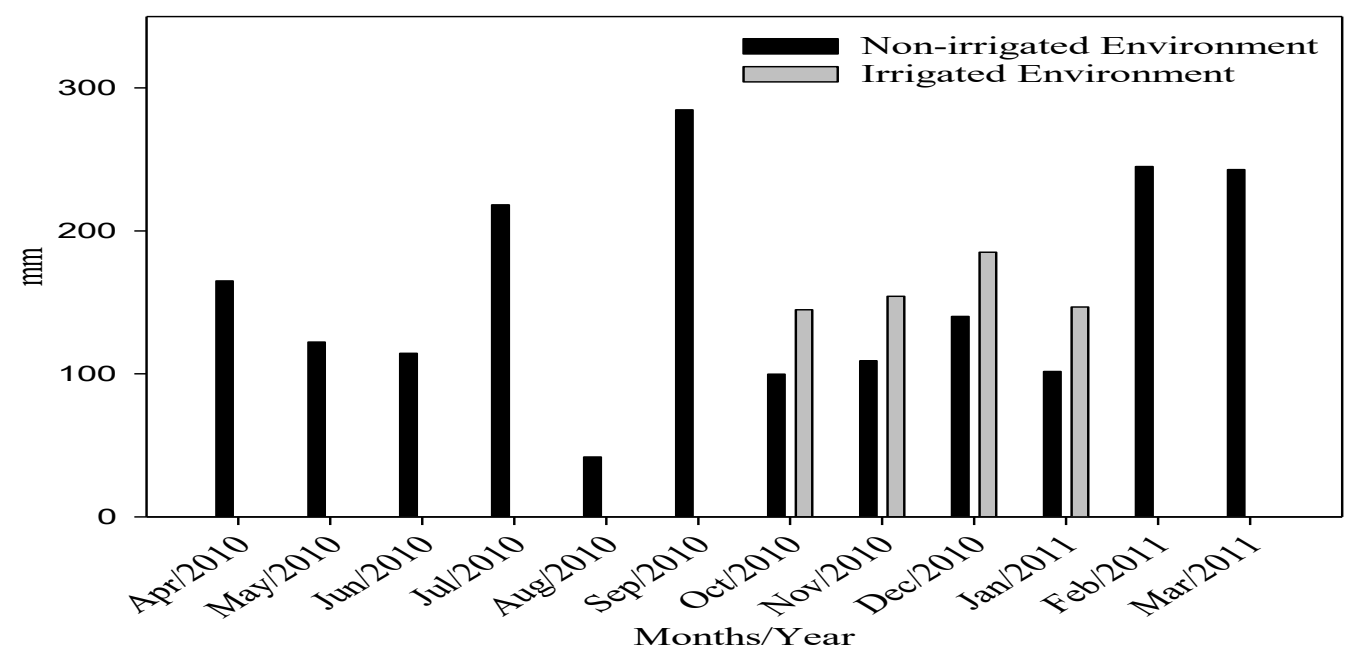

Figure 1 - Normal rainfall and irrigation addition means from April 2010 to March 2011 
meter $\left(\mathrm{mg} \mathrm{m}^{-2}\right)$; leaf area (LA): leaf length and width measurement, corrected by 0.73 to 0.75 factors (Montgomery, 1911); fresh matter per hectare $(\mathrm{FMH})$ : obtained by experimental unit grinding and matter measurement, with further adjustment for the final plant population per hectare $\left(\mathrm{kg} \mathrm{ha}^{-1}\right)$; dry matter per hectare $(\mathrm{DMH})$ : grinded matter was subjected to drying at $65^{\circ} \mathrm{C}$. After seven days, matter was measured and the final plants population per hectare was set up $\left(\mathrm{kg} \mathrm{ha}^{-1}\right)$; silage dry matter percentage (SDM): a fraction of the material was collected after "feed-out". Fractions were stored in an oven at $105^{\circ} \mathrm{C}$ for 24 hours. Afterwards, the ratio between fresh and dry matter mass was obtained; silage $\mathrm{pH}(\mathrm{pH})$; hemicellulose (HEM); cellulose (CEL); mineral material (MM): parameters obtained via technique of Silva and Queiróz (2006); neutral detergent fiber (NDF): samples were subjected to autoclaving with neutral detergent at $110{ }^{\circ} \mathrm{C}$ for 40 minutes; acid detergent fiber (ADF): NDF residue was autoclaved with acid detergent at $110^{\circ} \mathrm{C}$ for 40 minutes (Senger et al., 2008); lignin (LIG): measured through the methodology proposed by Robertson and Van Soest (1981); total carbohydrates (TC) and non-fibrous carbohydrates (NFC) were obtained by Sniffen et al. (1992) method; crude protein (CP): determined by methodology proposed by Nogueira and Souza (2005); lipids (LIP): determined by the technique presented by Bligh and Dyer(1959).
Data were submitted to analysis of variance by $F$ test. When significant at $p<0.05$, simple effects were dismembered between genotypes $x$ environments $(G \times E)$. In interaction absence, data were submitted to main effects comparison. Means were compared by Tukey with $\mathrm{p}<0.05$ error probability level.

\section{RESULTS AND DISCUSSION}

Analysis of variance was significant $(p<0.05)$ for environment xcorn hybrids interaction for plant height, fresh and dry matter per hectare, dry matter percentage, mineral matter, crude protein, neutral detergent fiber, lignin and total and non-fibrous carbohydrates. No interaction to chlorophyll content, leaf area, $\mathrm{pH}$, acid detergent fiber, hemicellulose, cellulose and lipids occurred. Significant difference absence was observed for lipids variable in the factors analyzed in this study.

Plant growth and the expression of relevant characteristics to the genotype are highly dependent on abiotic factors related to cultivation environment. In non-irrigated environments (Table 1), there is a similar behavior of the hybrids for these characteristics. In irrigated environment, there was plant height superiority of HT4 and HT7 hybrids in relation to the others.

Table 1 - Environment $x$ corn hybrids interaction means for plant height (PH), fresh matter yield per hectare (FMH) and dry matter yield per hectare variables (DMH), Campos Borges, 2014

\begin{tabular}{|c|c|c|c|c|c|}
\hline \multirow{3}{*}{ Corn hybrids } & \multicolumn{2}{|c|}{ PH (m) } & \multicolumn{2}{|c|}{ FMH $\left(\mathrm{kg} \mathrm{ha}^{-1}\right)$} & DMH $\left(\mathrm{kg} \mathrm{ha}^{-1}\right)$ \\
\hline & \multicolumn{5}{|c|}{ Environments } \\
\hline & Non-irrigated & Irrigated & Non-irrigated & Irrigated & Non-irrigated \\
\hline HT3248 & $1.42 \mathrm{aA}$ & $1.65 \mathrm{cA}$ & $28981.2 \mathrm{bcA}$ & $33269.9 \mathrm{bcdA}$ & $8907.3 \mathrm{abA} \quad 8076.1 \mathrm{cA}$ \\
\hline HS1356 & $1.52 \mathrm{aB}$ & $1.76 \mathrm{cA}$ & $28771.8 \mathrm{cB}$ & $42273.7 \mathrm{abA}$ & $7892.3 \mathrm{bB} \quad 10955.1 \mathrm{abA}$ \\
\hline HS1380-2 & $1.38 \mathrm{abB}$ & $1.72 \mathrm{cA}$ & $29404.2 \mathrm{bA}$ & $36997.4 \mathrm{bcA}$ & $8865.8 \mathrm{abA} \quad 10348.1 \mathrm{abA}$ \\
\hline HS1358 & $1.43 \mathrm{abB}$ & $1.70 \mathrm{cA}$ & $32828.3 \mathrm{abcA}$ & 35133.2 bcdA & $8595.3 \mathrm{abA} \quad 8794.8 \mathrm{abcA}$ \\
\hline HT7 & $1.26 \mathrm{bB}$ & $2.01 \mathrm{aA}$ & $34303.6 \mathrm{abB}$ & $45594.6 \mathrm{aA}$ & $9409.1 \mathrm{abA}$ \\
\hline HSM97 & $1.41 \mathrm{abA}$ & $1.62 \mathrm{cA}$ & $29388.2 \mathrm{bA}$ & 34075.2 bcdA & 7849.9 bA \\
\hline HS1380-1 & $1.57 \mathrm{aA}$ & $1.75 \mathrm{bA}$ & $40294.7 \mathrm{aA}$ & $26268.7 \mathrm{~dB}$ & $11448.3 \mathrm{aA}$ \\
\hline HT4 & $1.53 \mathrm{aB}$ & $1.85 \mathrm{abA}$ & $38493.2 \mathrm{abA}$ & $30772.5 \mathrm{cdA}$ & $10137.8 \mathrm{aA} \quad 9377.7 \mathrm{abcA}$ \\
\hline CV $(\%)$ & \multicolumn{2}{|c|}{8.53} & \multicolumn{2}{|c|}{16.28} & 18.21 \\
\hline $\mathrm{r}^{2}$ & \multicolumn{2}{|c|}{0.75} & \multicolumn{2}{|c|}{0.59} & 0.47 \\
\hline
\end{tabular}

*Means followed by the same lower case letter in the column and capital on the line do not statistically differ by Tukey test with ( $p<0.05$ ) error probability. 
Adequate water supply in technified corn hybrids provides grain yield and plant growth and development increases (Carvalho et al., 2014). Between environments, all hybrids had higher plant height in the irrigated system. Morphological characteristics directly affect the performance of genotypes aimed at silage production. Hybrids with high biomass yield and high nutrient levels are being increasingly sought (Ferrari Junior et al., 2005).

The chlorophyll molecule is involved in transforming solar radiation into chemical energy in the form of photoassimilates, supplying the required energy demand for plant development (Taiz and Zeiger, 2009). Chlorophyll content (Table 2) is higher in irrigated environments, providing better photosynthetic conditions for plants.

Leaf area (Table 2) show positive effects in irrigated environments compared to non-irrigated ones, where there was leaf reduction in the plant lower third. Hybrids productive potential is related to the solar radiation interception capability and leaf area. Similarity is evidenced among hybrids for chlorophyll content and leaf area characters.

Concerning fresh matter per hectare, HS13801 hybrid expressed superiority in non-irrigated environment (Table 1). Between environments, HS1356 and HT7 hybrids showed higher magnitudes of this parameter in irrigated environments. According to Silva et al. (2012), productive potential and morphological characteristics are highly correlated with genetic constitution, crop environment, management and employed technologies. Corn crop has high water demand throughout the cycle. Studies point needs of between 400-600 mm precipitation (Fancelli and Dourado Neto, 2004).

Precipitation occurred during the study period (Figure 1) revealed magnitudes that were lower than $200 \mathrm{~mm}$. Plants subjected to water stress periods have tendency to show leaf area decrease, stomatal closure and accelerated senescence of its leaves (Taiz and Zeiger, 2009). In irrigated environment, HT7was superior to the other hybrids. Between environments, the irrigated system provided higher fresh matter yields per hectare to HS1356 and HT7 hybrids.

For the dry mass per hectare, there was HS13801 hybrid superiority, producing $11448.3 \mathrm{~kg} \mathrm{ha}^{-1}$ in non-irrigated environment (Table 1). Between environments, HS 1356 hybrid performed better in irrigated environment. HT 3248, HS 1380-2, HS 1358, HT 7, HSM 97 and HT 4 hybrids showed no

Table 2 - Environment means and corn hybrids for chlorophyll content (CC), leaf area (LA), silage pH (pH), acid detergent fiber (ADF), cellulose (CEL), hemicellulose (HEM) and lipid (LIP) variables, Campos Borges, 2014

\begin{tabular}{cccccccc}
\hline Environments & $\mathrm{CC}\left(\mathrm{mg} \mathrm{m}^{-2}\right)$ & LA $\left(\mathrm{cm}^{2}\right)$ & $\mathrm{pH}$ & ADF (\%) & CEL (\%) & HEM (\%) & LIP (\%) \\
\hline Non-irrigated & $14.61 \mathrm{~b}$ & $5801.90 \mathrm{~b}$ & $3.76 \mathrm{~b}$ & $20.10 \mathrm{~b}$ & $19.59 \mathrm{~b}$ & $29.59 \mathrm{a}$ & $3.69 \mathrm{a}$ \\
Irrigated & $16.13 \mathrm{a}$ & $6379.00 \mathrm{a}$ & $3.83 \mathrm{a}$ & $23.29 \mathrm{a}$ & $22.36 \mathrm{a}$ & $30.94 \mathrm{a}$ & $3.73 \mathrm{a}$ \\
& \multicolumn{7}{c}{ Corn hybrids } \\
\hline HT3248 & $14.77 \mathrm{a}$ & $6417.00 \mathrm{a}$ & $3.75 \mathrm{a}$ & $19.35 \mathrm{a}$ & $31.59 \mathrm{ab}$ & $19.20 \mathrm{a}$ & $3.59 \mathrm{a}$ \\
HS1356 & $15.90 \mathrm{a}$ & $6511.30 \mathrm{a}$ & $3.73 \mathrm{a}$ & $21.41 \mathrm{a}$ & $33.83 \mathrm{a}$ & $20.74 \mathrm{a}$ & $3.59 \mathrm{a}$ \\
HS1380-2 & $15.90 \mathrm{a}$ & $6258.30 \mathrm{a}$ & $3.76 \mathrm{a}$ & $21.58 \mathrm{a}$ & $30.21 \mathrm{ab}$ & $20.71 \mathrm{a}$ & $3.56 \mathrm{a}$ \\
HS1358 & $16.27 \mathrm{a}$ & $5931.50 \mathrm{a}$ & $3.78 \mathrm{a}$ & $23.91 \mathrm{a}$ & $29.89 \mathrm{ab}$ & $22.79 \mathrm{a}$ & $3.89 \mathrm{a}$ \\
HT7 & $15.70 \mathrm{a}$ & $5541.90 \mathrm{a}$ & $3.92 \mathrm{a}$ & $22.29 \mathrm{a}$ & $29.04 \mathrm{~b}$ & $21.80 \mathrm{a}$ & $4.02 \mathrm{a}$ \\
HSM97 & $14.13 \mathrm{a}$ & $6034.80 \mathrm{a}$ & $3.80 \mathrm{a}$ & $21.72 \mathrm{a}$ & $28.48 \mathrm{~b}$ & $20.50 \mathrm{a}$ & $3.76 \mathrm{a}$ \\
HS1380-1 & $14.82 \mathrm{a}$ & $5795.20 \mathrm{a}$ & $3.82 \mathrm{a}$ & $23.18 \mathrm{a}$ & $28.79 \mathrm{~b}$ & $22.54 \mathrm{a}$ & $3.53 \mathrm{a}$ \\
HT4 & $15.47 \mathrm{a}$ & $6233.60 \mathrm{a}$ & $3.79 \mathrm{a}$ & $20.14 \mathrm{a}$ & $30.28 \mathrm{ab}$ & $19.20 \mathrm{a}$ & $3.75 \mathrm{a}$ \\
\hline CV $(\%)$ & 12.80 & 11.48 & 3.26 & 11.49 & 8.18 & 10.15 & 8.20 \\
$\mathrm{r}^{2}$ & 0.27 & 0.33 & 0.29 & 0.48 & 0.43 & 0.50 & 0.31 \\
\hline
\end{tabular}

*Means followed by the same lower case letter in the column do not statistically differ by Tukey test with $(p<0.05)$ error probability. 
differences between environments. Low dry matter yields are linked to high temperatures incidence, inadequate rainfall, leaf abscission in the plants lower third and decreased efficiency in plant nutrient use (Gazola et al., 2014).

Corn silage dry matter percentage must have magnitudes exceeding 30\% to ensure adequate fermentation and preservation of the ensiled material (Pinto et al., 2012). In non-irrigated environment such was observed with HT3248 and HS1380-2 hybrids (Table 3). Appropriate dry matter contents can characterize hybrids with high forage yield, nutritional quality and digestibility. In irrigated environment, different responses were expressed by HS1380-1 and HT4 hybrids. Among environments, HT4 hybrid shows $4.21 \%$ increase of dry matter percentage with irrigation. This characteristic is influenced by genotype characteristics, leaf architecture, photosynthetic efficiency and water demand. These combined factors provide morphological and reproductive structures satisfactory development.

Silage $\mathrm{pH}$ is an indicative parameter of the ensiled material conservation. In irrigated environment (Table 2), the $\mathrm{pH}$ is higher. Acid action and $\mathrm{pH}$ reduction restrict harmful bacteria but provide lactic bacteria population growth, with lactic acid rapid production and silage material stability.
Non-irrigated environment mineral matter (Table 3) was relevant superior to HT7 hybrid. Linhares et al. (2005) revealed $7.4 \%$ of mineral matter for corn silage. In irrigated environment, HS1356 and HT1358, hybrids were superior to the others.

Fibers on ruminant diets provide digestive tract effective functioning, facilitate nutrients absorption, increase dry matter intake and improve salivation. Neutral detergent fibers (Table 3) are superior to HS1356 and HT4 in non-irrigated environment. The characteristic is dependent on the amount of grenade cobs, whose silage mass gradual increase tends to reduce the product fibrous portion.

In irrigated environment, the neutral detergent fiber character revealed that HT 3248, HS 1356 and HT 7 hybrids were superior. Between environments, HT 3248, HS 1356, HS 1380-2, HS 1358 and HT 7 genotypes positively responded to irrigation. These results are justified by the circumstance of stems and leaves being quantitatively superior to grenade cobs. Some benefits were evidenced with high fiber content, such as higher food residence time in the rumen, better digestion and changes in the acetate and propionate rate.

Fibers are composed of pectin, cellulose, lignin, soluble nitrogen in acid reaction and ashes. Diets

Table 3 - Environment x corn hybrids interaction means for silage dry matter percentage (SDM), mineral matter (MM) and neutral detergent fiber (NDF) variables, Campos Borges, 2014

\begin{tabular}{|c|c|c|c|c|c|c|}
\hline \multirow{3}{*}{ Corn hybrids } & \multicolumn{2}{|c|}{ SDM (\%) } & \multicolumn{2}{|c|}{ MM (\%) } & \multicolumn{2}{|c|}{ NDF (\%) } \\
\hline & \multicolumn{6}{|c|}{ Environment } \\
\hline & Non-irrigated & Irrigated & $\begin{array}{l}\text { Non- } \\
\text { irrigated }\end{array}$ & Irrigated & $\begin{array}{c}\text { Non- } \\
\text { irrigated }\end{array}$ & Irrigated \\
\hline HT3248 & $30.60 \mathrm{aA}$ & $24.12 \mathrm{cB}$ & $3.25 \mathrm{cB}$ & $4.85 \mathrm{bA}$ & $47.89 \mathrm{abB}$ & $54.00 \mathrm{aA}$ \\
\hline HS1356 & $27.43 \mathrm{abA}$ & $25.94 \mathrm{bcA}$ & $2.77 \mathrm{~dB}$ & $6.36 \mathrm{aA}$ & $52.15 \mathrm{aB}$ & $58.34 \mathrm{aA}$ \\
\hline HS1380-2 & $30.20 \mathrm{aA}$ & $27.94 \mathrm{abA}$ & $4.01 \mathrm{bA}$ & $2.35 \mathrm{~dB}$ & $47.33 \mathrm{abB}$ & $56.27 \mathrm{abA}$ \\
\hline HS1358 & $26.07 \mathrm{bA}$ & $25.21 \mathrm{bcA}$ & $2.50 \mathrm{deB}$ & $6.41 \mathrm{aA}$ & $50.23 \mathrm{abB}$ & $57.39 \mathrm{abA}$ \\
\hline HT7 & $27.45 \mathrm{abA}$ & $26.00 \mathrm{bcA}$ & $4.55 \mathrm{aA}$ & $3.48 \mathrm{cB}$ & $46.61 \mathrm{bB}$ & $56.04 \mathrm{aA}$ \\
\hline HSM97 & $26.56 \mathrm{bA}$ & $29.28 \mathrm{aA}$ & $2.46 \mathrm{deA}$ & $2.46 \mathrm{dA}$ & $49.73 \mathrm{abA}$ & $50.68 \mathrm{cA}$ \\
\hline HS1380-1 & $28.40 \mathrm{abA}$ & $30.53 \mathrm{aA}$ & $2.46 \mathrm{deB}$ & $3.13 \mathrm{cA}$ & $51.29 \mathrm{abA}$ & $52.65 \mathrm{abA}$ \\
\hline HT4 & $26.23 \mathrm{bB}$ & $30.45 \mathrm{aA}$ & $2.31 \mathrm{eB}$ & $3.32 \mathrm{cA}$ & $52.33 \mathrm{aA}$ & $48.51 \mathrm{dA}$ \\
\hline CV (\%) & \multicolumn{2}{|c|}{6.44} & \multicolumn{2}{|c|}{7.50} & \multicolumn{2}{|c|}{6.13} \\
\hline $\mathrm{r}^{2}$ & \multicolumn{2}{|c|}{0.68} & \multicolumn{2}{|c|}{0.97} & \multicolumn{2}{|c|}{0.66} \\
\hline
\end{tabular}

*Means followed by the same lower case letter in the column and capital on the line do not statistically differ by Tukey test with ( $p<0.05)$ error probability. 
with adequate fiber levels provide efficient nutrient use by the digestive tract, keeping the lipid rates in milk through propionic acid. Fiber in acid digestion (Table 2) showed similarity among hybrids in the irrigated environment. Dry matter intake by ruminants is metabolic controlled and express high correlation with volatile fatty acids production (Mertens, 1994).

Cell wall constituents suffer large interference due to fermentation, causing secondary effluent by-product formation in acid form (Van Soest, 1994). Cellulose (Table 2) was more influenced by environment factor when compared to the genetic differences among hybrids, and superior effects were observed for the irrigated environment. Hemicellulose character (Table 2) was similar between environments, with difference between hybrids, in which the HS 1356 genotype revealed superior. Forage grasses show differences and oscillations due to silage storage time on neutral and acid detergent fiber, cellulose and lignin (Pesce et $a l ., 2000)$. The results obtained in the study are justifiable due to the long storage silage time and low degradation of compounds that would be transformed into fibrous elements.

Lignin has structural importance, conferring resistance, integrity, impermeability and preventing tissue degradation. For ruminants, this fraction is not used in their nutrition. Van Soest (1994) showed direct interference in this component via growth environment changes. In non-irrigated environment (Table 4), the HS1358 hybrid was superior in lignin. Results were inferior to those obtained by Pimentel et al. (1998), which obtained 5\% to 8\% variation in corn and sorghum silages. The environment causes differences in hybrid responses, with strong lignification for the HSM97 genotype in irrigated environment.

Between environments, HT3248, HSM97 and HS1380-1 hybrids were superior in lignin in the irrigated environment. Better water conditions provide hybrids rapid cell expansion, with tissue lignification process anticipation. Studies of Possenti et al. (2005) with corn silage showed direct dependence of lignin percentage $(3.7 \%)$ and stem proportion of corn.

Carbohydrates are characterized as energy sources in the diet of ruminants, and become effective when combined with nitrogen compounds availability.
These are the basis for the food protein fraction and rumen microbial flora efficiency gains, with quantitative additions in animal carcass (Van Soest, 1994). Total carbohydrates (Table 4) had magnitudes of above $88 \%$ in both environments, for all hybrids. Lower results were reported by Cabral et al. (2002), who obtained $84.4 \%$ in corn silage.

Between environments, HS1356 hybrid was superior in the non-irrigated environment. This character consists of the following fractions; rapid degradation sugars, starches and pectins, slowly degrading fiber and non-digestible elements (Sniffen et al., 1992). Total carbohydrate additions are related to fiber proportion and, to a lesser extent, to proteins and lipids.

High dry matter corn silage is dependent on grenade cobs proportion, influencing non-fibrous carbohydrates. In non-irrigated environments, HT3248, HS1356, HS1380-2, HS1358, HT7, HSM97 and HS1380-1 hybrids proved superior concerning to dry matter content. For ruminants, high dry matter content provides energy supply to the diet, maximizing rumen microbial flora efficiency (Russell et al., 1992).

In the irrigated environment, HSM97, HS1380-1 and HT4 hybrids presented higher non-fiber carbohydrate contents (Table 5).Between environments, HT3248, HS1356, HS1380-2, HS1358 and HT7hybrids showed superior behavior in the non-irrigated environment. According to Cabral et al. (2002), in order to obtain silage with $30 \%$ to $50 \%$ non-fiber carbohydrates, between $15 \%$ to $45 \%$ grenade cobs in the corn silage mass are needed. Balanced diets with carbohydrate and protein proportions with the same fermentation degree allow additions for microbial protein formation, which enhances microorganism action in the rumen, although demanding more food proteins.

In non-irrigated environment HS1358 and HT4 corn hybridsdiffer from other genotypes, with higher crude protein percentage (Table 5). Pimentel et al. (1998) found between $5 \%$ to $6 \%$ crude protein in different silage corn hybrids. In the irrigated environment, HS1356, HT7, HSM97, HS1380-1 and HT4 hybrids were superior for crude protein percentage. Between environments, HS 1358 and HT4 hybrids showed the best performance in non-irrigated environment. Oscillations are related to differences in silage compression and nitrogen solutes production, which interfere on crude protein. 
Table 4 - Environment x corn hybrids interaction means for lignin (LIG) and total carbohydrate (TC) variables, Campos Borges, 2014

\begin{tabular}{|c|c|c|c|c|}
\hline \multirow{3}{*}{ Corn hybrids } & \multicolumn{2}{|c|}{ LIG (\%) } & \multicolumn{2}{|c|}{ TC (\%) } \\
\hline & \multicolumn{4}{|c|}{ Environments } \\
\hline & Non-irrigated & Irrigated & Non-irrigated & Irrigated \\
\hline HT3248 & $0.00 \mathrm{eB}$ & $0.90 \mathrm{cA}$ & $93.43 \mathrm{aA}$ & $91.76 \mathrm{aA}$ \\
\hline HS1356 & $0.62 \mathrm{cA}$ & $0.46 \mathrm{de} A$ & $92.49 \mathrm{abA}$ & $88.33 \mathrm{bB}$ \\
\hline HS1380-2 & $0.67 \mathrm{cA}$ & $0.90 \mathrm{cA}$ & $91.39 \mathrm{bcA}$ & $92.76 \mathrm{aA}$ \\
\hline HS1358 & $2.77 \mathrm{aA}$ & $0.22 \mathrm{eB}$ & $89.76 \mathrm{cA}$ & $88.92 \mathrm{bA}$ \\
\hline HT7 & $0.87 \mathrm{cA}$ & $0.67 \mathrm{cdA}$ & $90.03 \mathrm{cA}$ & $91.57 \mathrm{aA}$ \\
\hline HSM97 & $0.55 \mathrm{~dB}$ & $2.36 \mathrm{aA}$ & $91.67 \mathrm{abcA}$ & $91.27 \mathrm{aA}$ \\
\hline HS1380-1 & $0.38 \mathrm{~dB}$ & $1.26 \mathrm{bA}$ & $91.97 \mathrm{abcA}$ & $91.57 \mathrm{aA}$ \\
\hline HT4 & $1.04 \mathrm{bcA}$ & $0.21 \mathrm{~dB}$ & $90.59 \mathrm{cA}$ & $91.59 \mathrm{aA}$ \\
\hline CV (\%) & \multicolumn{2}{|c|}{19.10} & \multicolumn{2}{|c|}{7.97} \\
\hline $\mathrm{r}^{2}$ & \multicolumn{2}{|c|}{0.96} & \multicolumn{2}{|c|}{0.75} \\
\hline
\end{tabular}

*Means followed by the same lower case letter in the column and capital on the line do not statistically differ by Tukey test with ( $p<0.05$ ) error probability.

Table 5 - Environment $x$ corn hybrids interaction means for non-fibrous total carbohydrates (FTC) and crude protein (CP) variables, Campos Borges, 2014

\begin{tabular}{|c|c|c|c|c|}
\hline \multirow{3}{*}{ Corn hybrids } & \multicolumn{2}{|c|}{ FTC (\%) } & \multicolumn{2}{|c|}{ CP (\%) } \\
\hline & \multicolumn{4}{|c|}{ Environments } \\
\hline & Non-irrigated & Irrigated & Non-irrigated & Irrigated \\
\hline HT3248 & $41.92 \mathrm{aA}$ & $34.50 \mathrm{bB}$ & $3.31 \mathrm{dA}$ & $3.08 \mathrm{dA}$ \\
\hline HS1356 & $37.10 \mathrm{aA}$ & $27.39 \mathrm{cB}$ & $4.50 \mathrm{cA}$ & $4.16 \mathrm{abcA}$ \\
\hline HS1380-2 & $40.90 \mathrm{aA}$ & $34.25 \mathrm{bB}$ & $4.13 \mathrm{cA}$ & $3.59 \mathrm{bcA}$ \\
\hline HS1358 & $36.69 \mathrm{abA}$ & $28.81 \mathrm{cB}$ & $6.78 \mathrm{aA}$ & $3.37 \mathrm{cdB}$ \\
\hline HT7 & $39.79 \mathrm{aA}$ & $32.06 \mathrm{bcB}$ & $5.11 \mathrm{bcA}$ & $4.26 \mathrm{abcA}$ \\
\hline HSM97 & $38.80 \mathrm{abA}$ & $38.62 \mathrm{aA}$ & $5.12 \mathrm{bA}$ & $4.55 \mathrm{abA}$ \\
\hline HS1380-1 & $37.42 \mathrm{abA}$ & $36.40 \mathrm{abA}$ & $5.16 \mathrm{bA}$ & $4.39 \mathrm{abA}$ \\
\hline HT4 & $35.66 \mathrm{bA}$ & $39.34 \mathrm{aA}$ & $6.05 \mathrm{abA}$ & $4.93 \mathrm{aB}$ \\
\hline CV (\%) & \multicolumn{2}{|c|}{7.97} & \multicolumn{2}{|c|}{12.95} \\
\hline $\mathrm{r}^{2}$ & \multicolumn{2}{|c|}{0.75} & \multicolumn{2}{|c|}{0.81} \\
\hline
\end{tabular}

* Means followed by the same lower case letter in the column and capital on the line do not statistically differ by Tukey test with ( $\mathrm{p}<0.05$ ) error probability. 


\section{CONCLUSIONS}

In irrigated environment, hybrids showed higher plant height, chlorophyll content, leaf area, fresh and dry matter per hectare, silage dry matter percentage, silage $\mathrm{pH}$, mineral material, neutral detergent fiber, cellulose and lignin.

Non-fiber carbohydrate and total carbohydrate levels are parameters with higher magnitude in non-irrigated environment, regardless of hybrid.
Crude protein content is higher in the non-irrigated environment than in the irrigated environment, regardless of hybrid. In irrigated environment, HT4 hybrid had higher silage crude protein content.

The HS1356 hybrid was superior in irrigated environment compared to the other evaluated hybrids for plant height, fresh and dry matter per hectare, mineral matter and neutral detergent fiber. In non-irrigated conditions, this same hybrid has higher total carbohydrate and non-fibrous carbohydrate content.

\section{REFERENCES}

Bligh, E.G. e Dyer, W.J.A. (1959) - A rapid method of total lipid extraction and purification. Canadian Journal of Physiology and Biochemistry, vol. 37, n. 8, p. 911-917. http://dx.doi.org/10.1139/o59-099

Cabral, L.S.; Valadares Filho, S.C.; Detmann, E.; Zervoudakis, J.T.; Pereira, O.G.; Veloso, R.G. and Pereira, E.S. (2002) - Ruminal kinetics of fractions of carbohydrates, gas production, in vitro digestibility of dry matter and TDN estimated corn silage with different grain proportions. Revista Brasileira de Zootecnia, vol. 31, n. 6, p. 2332-2339. http://dx.doi.org/10.1590/S1516-35982002000900023

Carvalho, I. R.; Korcelski, C.; Pelissari, G. and Hannus, A.D. (2013) - Hydro demand of cultures agronomic interest. Enciclopédia Biosfera. vol. 9, p. 969-975.

Carvalho, I.R.; Souza, V.Q.; Follmann, D.N.; Nardino, M. and Schmidt, D. (2014) -Agronomic performance of corn hybrids in irrigated and rainfed environment. Enciclopédia Biosfera, vol. 10, p. 1144-1153.

Fancelli, A.L. and Dourado-Neto, D. (2004) - Corn production. Guaiba: $2^{\circ}$ Ed. Agropecuária. Porto Alegre, 360p.

Ferrari Junior, E.; Possenti, R.A.; Lima, M.L.; Nogueira, J.R. and Andrade, J.B. (2005) - Characteristics, chemical composition and quality silage eight corn cultivars. Boletim de Indústria Animal, vol. 62, p. 19-27.

Gazola, D.; Zucarelli, C.; Raphael, R. and Fonseca, B. (2014) - Foliar application of amino acids and nitrogen fertilization coverage in safrinha corn culture. Revista Brasileira de Engenharia Agrícola e Ambiental. vol. 18, n. 7, p. 700-707. http://dx.doi.org/10.1590/S1415-43662014000700005

Linhares, P.C.F.; Maracajá, P.B.; Filho, J.L.; Vasconcelos, S.H.L. and Nunes, G.H. (2005) -Jitirana inclusion in Chemical Chemical Composition of Corn Silage. Caatinga, vol. 18, n. 2, p. 117-122.

Mertens, D.R. (1994) - Regulation of Forage Intake. $1^{\circ}$ Ed. University of Nebraska. Lincoln, 250 p.

Montgomery, E.G. (1911) - Correlation studies of corn. Annual report, Agricultural Experiment Station. vol. 1, p. 108-159.

Nogueira, A.R.A. and Souza, G.B. (2005) - Laboratory Manual: Soil, Water, Crop Nutrition, Animal Nutrition and Food. $1^{\circ}$ Ed. Embrapa Pecuária Sudeste, São Carlos, 313 p.

Pesce, D.M.C.; Gonçalves, L.C. e Santos, J. (2000) - Analysis twenty genotypes of sorghum (Sorghum bicolor (L.) Moench), portes medium and high, belonging to the national essay. Revista Brasileira de Zootecnia, vol. 29, n. 4, p. 978-987. http://dx.doi.org/10.1590/S1516-35982000000400006

Pimentel, J.J.O.; Coelho, J.F.; Valadares, F.; Campos, S.; Cecon, P.R. and Santos, O.S. (1998) - Protein supplementation effect on nutritional value silage corn and sorghum. Revista Brasileira de Zootecnia, vol. 27, p. 1042-1049.

Pinto, A.P.; Mizubuti, I.Y.; Ribeiro, E.L.; Pereira, E.S.; Bumbieris Junior, V.H.; Pimentel, P.G.; Salmazo, R. and Carneiro, I.R.O. (2012) - Evaluation of orange peel and corn silages with different protein additives. Semina, vol. 33, s. 2, p. 3305-3314.

Possenti, R.A.; Ferrari, J.R.E.; Bueno, M.S.; Bianchivi, D.; Leinz, F.F. and Rodrigues, C.F.C. (2005) - Bromatological and fermentation parameters of corn and sunflower silages. Ciência Rural, vol. 35, n. 5, p. 11851189. http://dx.doi.org/10.1590/S0103-84782005000500031

Robertson, J.B. and Van Soest, P.J. (1981) - The detergent system of analysis and its application to human 
foods. In:James, W.P.T. and Theander, O. (Eds.) - The analysis of dietary fiber in foods. Marcel Dekker, New York, NY.

Russel, B.J. and O'Connor, J.D.A. (1992) - A net carbohydrate and protein system for evaluation cattle diets: I. ruminal fermentation. Journal of Animal Science, vol. 70, n. 11, p. 3551-3581.

Senger, C.C.D.; Kozloski, G.V.; Sanchez, L.M.B.; Mesquita, F.R.; Alves, T.P. and Castagnino, D.S. (2008) Evaluation of autoclave procedures for fibre analysis in forage and concentrate feedstuffs. Animal Feed Science and Technology. vol. 146, n. 1-2, p. 169-174. http://dx.doi.org/10.1016/j.anifeedsci.2007.12.008

Silva, D.J. and Queiroz, C. (2006) - Food Analysis: Methods Chemical and Biological. $1^{\circ}$ Ed Universidade Federal de Viçosa, Viçosa.

Silva, M.R.; Martin, T.N., Ortiz, S.; Bertoncelli, P. and Vonz, D. (2012) - Agronomic performance of corn genotypes under water restriction. Revista de Ciências Agrárias, vol 35, n. 1, p. 200-210.

Sniffen, C.J.; O'Connor, D.J.; Van Soest, P.J.; Fox, D.G. and Russell, J.B. (1992) - A net carbohydrate and protein system for evaluating cattle diets: II. carbohydrate and protein availability. Journal of Animal Science. vol. 70, n.11, p. 3562-3577.

Van Soest (1994) -Nutritional Ecology of the Ruminant. $2^{\circ}$ Ed Cornell University Press, New York, 512p.

Taiz, L. and Zeiger, E. (2009) -Fisiologia Vegetal. $4^{\circ}$ Ed. Artmed, Porto Alegre, 722p. 